SJîñn Jurnal

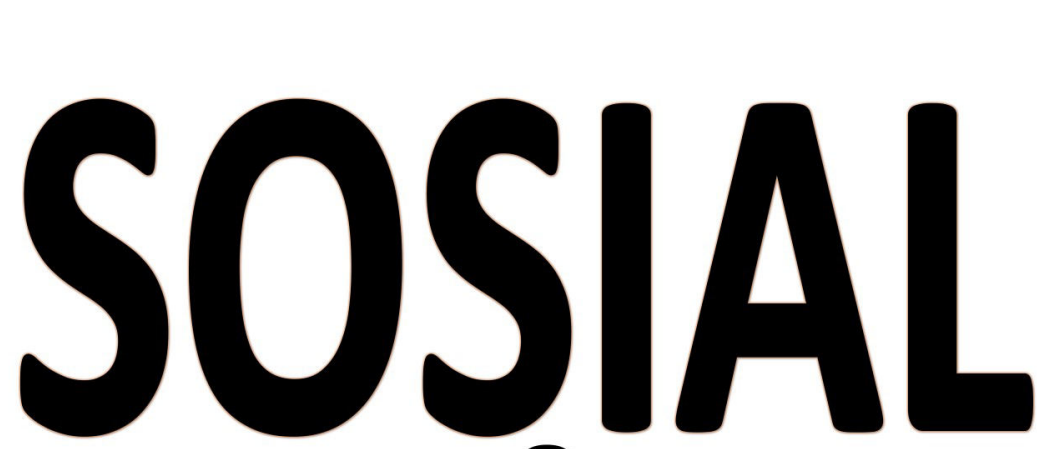

P-ISSN: 2356-1459 E-ISSN: 2654-9050 Vol. 7 No. 3 (2020)
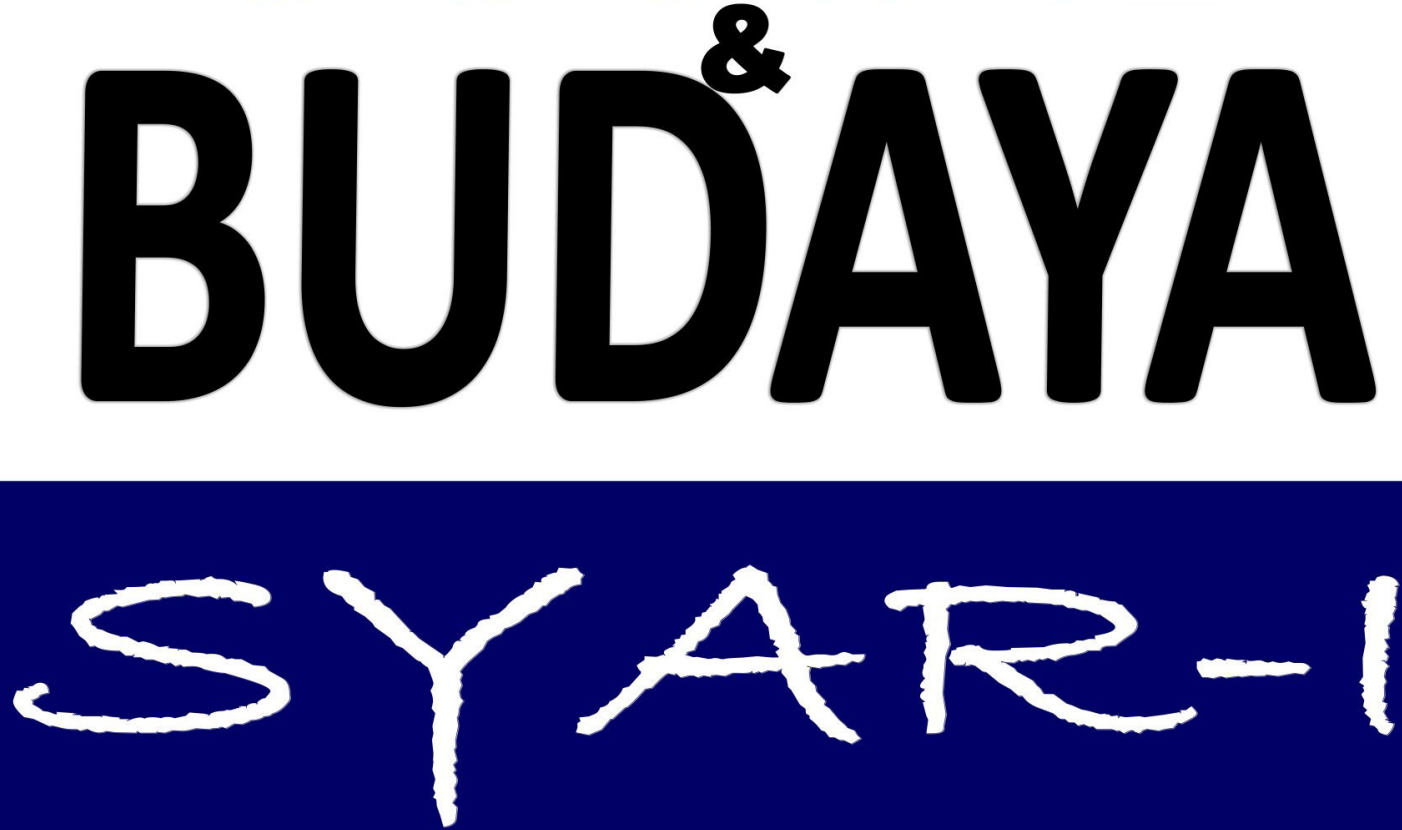

Konsep Tafakkur Dalam Alquran Dalam Menyikapi Coronavirus Covid-19 Indriya

Analisis Perilaku Masyarakat Indonesia dalam Menghadapi Pandemi Virus Corona (Covid-19) dan-

Kiat Menjaga Kesejahteraan Jiwa

Dana Riksa Buana

Kebijakan Pemberlakuan Lock Down Sebagai Antisipasi Penyebaran Corona Virus Covid-19

Nur Rohim Yunus, Annissa Rezki

Kebijakan Nabi Muhammad Saw Menangani Wabah Penyakit Menular dan Implementasinya dalam-

Konteks Menanggulangi Coronavirus Covid-19

Mukharom, Havis Aravik

Langkah Taktis Pemerintah Daerah Dalam Pencegahan Penyebaran Virus Corona Covid-19 di Indonesia Zahrotunnimah

Penggunaan Masker Penutup Wajah Saat Salat Sebagai Langkah Pencegahan Wabah Coronavirus Covid-19 Syandri, Fadhlan Akbar

Impact of Corona Virus Outbreak Towards Teaching and Learning Activities in Indonesia

Zaharah, Galia Ildusovna Kirilova, Anissa Windarti 


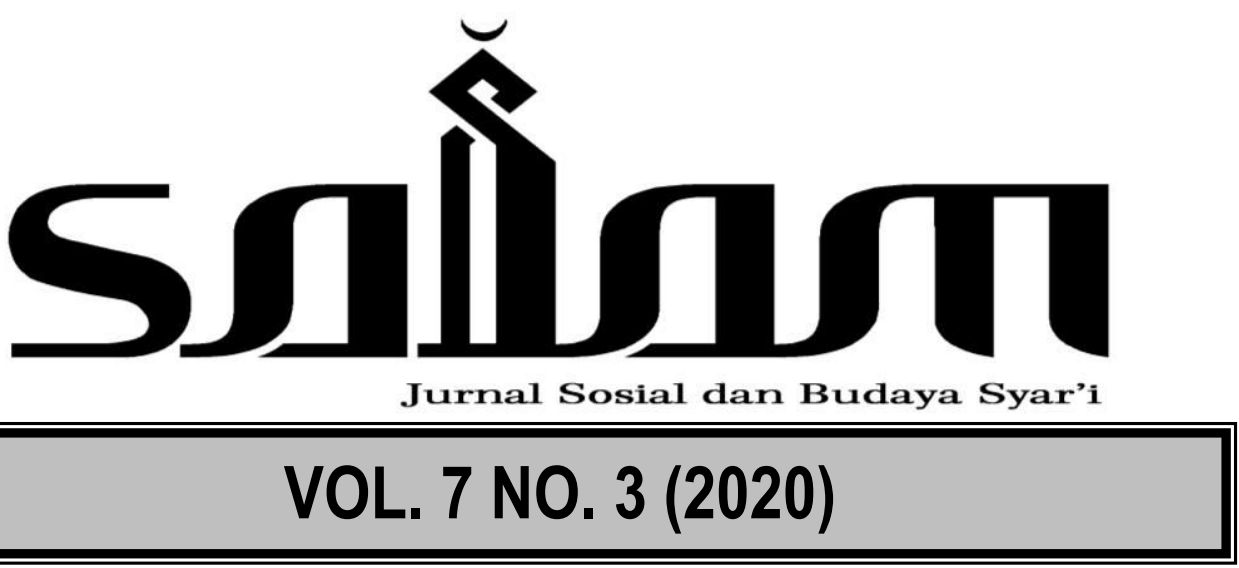

Diterbitkan oleh Fakultas Syariah dan Hukum Universitas Islam Negeri (UIN) Syarif Hidayatullah Jakarta.

Salam; Jurnal Sosial dan Budaya Syar-i mengkhususkan diri dalam pengkajian ilmu-ilmu Sosial dan Budaya dalam dimensi Syariah.

Terbit tiga kali dalam satu tahun di setiap bulan April, Agustus, dan Desember.

\section{Redaktur Ahli}

Muhammad Amin Suma (UIN Syarif Hidayatullah Jakarta) A Salman Maggalatung (UIN Syarif Hidayatull ah Jakarta) Asep Saepudin Jahar (UIN Syarif Hidayatullah Jakarta) Ahmad Mukri Aji (UIN Syarif Hidayatullah Jakarta) JM Muslimin (UIN Syarif Hidayatullah Jakarta) Muhammad Munir (IIU Islamabad Pakistan)

Euis Amalia (UIN Syarif Hidayatullah Jakarta)

Tim Lindsey (Melbourne University Australia)

Raihanah Azahari (University Malaya Malaysia)

Ahmad Tholabi (UIN Syarif Hidayatullah Jakarta)

Ahmad Hidayat Buang (University Malaya Malaysia)

\section{Pemimpin Redaksi \\ Erwin Hikmatiar}

\section{Sekretaris Redaksi}

Muhammad Ishar Helmi

Redaktur Pelaksana

Mara Sutan Rambe

Indra Rahmatullah

Nur Rohim Yunus

\section{Tata Usaha}

Imas Novita Juaningsih

Azizah Ratu Buana

\section{Alamat Redaksi}

Fakultas Syariah dan Hukum UIN Syarif Hidayatullah Jakarta Jl. Ir. H. Juanda 95 Ciputat Jakarta 15412 Telp. (62-21) 74711537, Faks. (62-21) 7491821

Website: www.fsh-uinjkt.net, E-mail: jurnal.salam@uinjkt.ac.id

Permalink: http://journal.uinjkt.ac.id/index.php/salam 


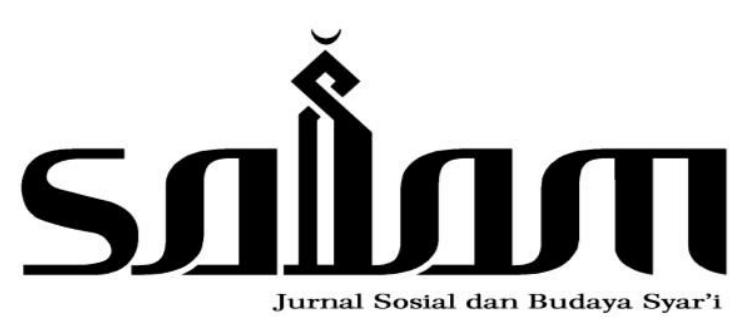

Menyambut baik kontribusi dari para ilmuwan, sarjana, profesional, dan peneliti dalam disiplin ilmu hukum untuk dipublikasi dan disebarluaskan setelah melalui mekanisme seleksi naskah, telaah mitra bebestari, dan proses penyuntingan yang ketat. 


\section{DAFTAR ISI}

\section{1-216}

Konsep Tafakkur Dalam Alquran Dalam Menyikapi Coronavirus Covid-19 Indriya

\section{7-226}

Analisis Perilaku Masyarakat Indonesia dalam Menghadapi Pandemi Virus Corona (Covid-19) dan Kiat Menjaga Kesejahteraan Jiwa

Dana Riksa Buana

\section{7-238}

Kebijakan Pemberlakuan Lock Down Sebagai Antisipasi Penyebaran Corona Virus Covid-19

Nur Rohim Yunus, Annissa Rezki

\section{9-246}

Kebijakan Nabi Muhammad Saw Menangani Wabah Penyakit Menular dan Implementasinya dalam Konteks Menanggulangi Coronavirus Covid-19 Mukharom, Havis Aravik

\section{7-260}

Langkah Taktis Pemerintah Daerah Dalam Pencegahan Penyebaran Virus Corona Covid-19 di Indonesia

Zahrotunnimah

\section{1-268}

Penggunaan Masker Penutup Wajah Saat Salat Sebagai Langkah Pencegahan Wabah Coronavirus Covid-19

Syandri, Fadhlan Akbar

\section{9-282}

Impact of Corona Virus Outbreak Towards Teaching and Learning Activities in Indonesia

Zaharah, Galia Ildusovna Kirilova, Anissa Windarti 



\title{
Penggunaan Masker Penutup Wajah Saat Salat Sebagai Langkah Pencegahan Wabah Coronavirus Covid-19*
}

\author{
Syandri, ${ }^{1}$ Fadhlan Akbar ${ }^{2}$ \\ Sekolah Tinggi Ilmu Islam dan Bahasa Arab (STIBA) Makassar \\ do \\ $\underline{10.15408 / \text { sjsbs.v7i3.15105 }}$
}

\begin{abstract}
This study discusses the spread of the Corona virus throughout the world, intended in Indonesia to find solutions, especially in carrying out the rituals of prayer in Islam. This study uses a descriptive qualitative method by using data related to the use of face or mouth coverings (masks) when carrying out the prayers that are affirmed as understood from the prohibition of the Prophet. The results of this study indicate that the law of origin using the mouth cover (mask) when prayer is makruh tanzih or makruh which does not cancel the prayer. However, in certain conditions such as the existence of intent, then using a legal mask may. It could even be increased to the law recommended if a person who will attend congregational prayers in unhealthy conditions such as fever, cough or flu. This is expected to prevent the spread of the Corona virus in the community.
\end{abstract}

Keywords: Masks, Face masks, Corona, Salat

\begin{abstract}
Abstrak
Penelitian ini membahas tentang merebaknya virus Corona di seluruh dunia termaksud di Indonesia untuk menemukan solusi khususnya dalam melaksanakan ritual ibadah salat dalam Islam. Penelitian ini menggunakan metode deskriptif kualitatif dengan menggunakan data yang berhubungan dengan penggunaan penutup wajah atau mulut (masker) saat melaksanakan ibadah salat yang dimakruhkan sebagaimana difahami dari pelarangan Rasulullah saw. Hasil penelitian ini memperlihatkan bahwa hukum asal menggunakan penutup mulut (masker) ketika salat adalah makruh tanzih yaitu makruh yang tidak membatalkan salat. Akan tetapi pada kondisi tertentu seperti adanya hajat, maka menggunakan masker hukumnya boleh. Bahkan bisa meningkat kepada hukum dianjurkan jika seorang yang akan menghadiri salat jamaah dalam kondisi kurang sehat seperti demam, batuk atau flu. Hal ini diharapkan dapat mencegah tersebarnya virus Corona dalam masyarakat.
\end{abstract}

Kata Kunci: Masker, Penutup wajah, Corona, Salat

\footnotetext{
*Diterima: 18 Februari 2020, Revisi: 20 Februari 2020, Diterbitkan 18 Maret 2020.

${ }^{1}$ Syandri adalah Dosen Sekolah Tinggi Ilmu Islam dan Bahasa Arab (STIBA) Makassar. E-mail: Syandri@Stiba.ac.id

${ }^{2}$ Fadhlan Akbar adalah Dosen Sekolah Tinggi Ilmu Islam dan Bahasa Arab (STIBA) Makassar. Email: Fadhlanakbar@stiba.ac.id
} 


\section{Pendahuluan}

Sejatinya kehidupan manusia itu penuh dengan beragam ujian dan tantangan yang silih berganti akan dilalui oleh manusia sepanjang kehidupannya tak terkecuali seorang muslim. Pergantian dari suatu kondisi ke kondisi berikutnya sudah merupakan sunnatullah yang pasti terjadi. Hari ini kita dihadapkan pada suatu kondisi yang sangat mencekam, lagi sulit, dimana wabah virus yang dikenal dengan nama virus Covid-19 merebak hampir di seluruh penjuru dunia, termasuk Indonesia.

Masyarakat Indonesia yang umumnya adalah kaum muslimin, dalam kondisi seperti ini terkadang menjadi bingung tentang kayfiyat atau tata cara pelaksanaan beberapa ritual ibadah wajib yang disyariatkan dalam agamanya dengan baik. Apalagi kondisi seperti ini menuntut seseorang untuk menggunakan Alat Pelindung Diri (APD) untuk melindungi diri dari penularan wabah virus saat melaksanakan ibadah wajib seperti salat Lima waktu.

Ibadah dalam Islam khususnya salat sudah memiliki aturan-aturan yang paten, dimana setiap orang tidak diperkenankan secara bebas untuk ber-ijtihad sesuai keinginannya dalam melaksanakan ibadah tersebut. Mulai dari syarat sah, rukun, sunnah, makruh, bahkan sampai pembatal-pembatal salat semuanya telah jelas dipaparkan oleh para ulama berdasarkan dalil-dalil yang ada. Meskipun pada beberapa kondisi tertentu, aturan-aturan ini boleh saja berubah, jika ada hajat atau maslahat yang menuntut perubahan tersebut.

Oleh karena itu, dalam penjelasan ringkas ini akan diuraikan jawaban atas pertanyaan yang kerap muncul di tengah merebaknya wabah virus Covid-19 yaitu hukum penggunaan masker atau kain yang menutup mulut dan hidung saat melaksanakan salat sebagai langkah pencegahan dari penularan wabah ini.

Dari permasalahan diatas, maka penulis mengajukan beberapa pertanyaan sebagai acuan dalam pembahasan, yaitu: Bagaimana hukum menggunakan penutup wajah pada saat salat? Bagaimana hukum menggunakan penutup wajah saat salat dalam kondisi darurat?

\section{Analisis dan Pembahasan}

\section{Pengertian Penutup Wajah}

Penutup wajah dalam terminologi Islam memiliki beberapa istilah, diantaranya: التثلث al talaśsum (menggunakan penutup wajah/topeng) biasanya untuk pria sedangkan penutup wajah bagi wanita dikenal dengan istilah النقاب al-Niqāb.

\section{a. Definisi At Talatstsum}

Dalam kitab Lisān Al Arab disebutkan bahwa al talaśṡum dari segi etimologi adalah menutup hidungnya dengan menggunakan kain. ${ }^{3}$ sedangkan dalam $M u^{\prime} j a m ~ A l$

${ }^{3}$ Muhammad Ibn Mukaram Manẓūr Al Afrīqī Al Mișrī, Lisan Al Arab, Volume 12. (Bairūt; Dār Șādir, t.t), 533. 
Mā̄'nī disebutkahan bahwa at-Talatssum adalah ketika seseorang menutup mulut dan hidungnya menggunakan kain atau imamah.

Menurut madzhab al Syāfiiyyah al talatssum adalah menutup mulut, madzhab al Hanābilah dan al Hanafiyah mendefenisikan menutup mulut dan hidung secara bersamaan, sedangkan madzhab al Mālikiyah berpendapat kain yang menutupi mulut sampai bibir bagian bawah. ${ }^{4}$

Dalam terminologi Islam, al talaśṡum bermakna menutup hidung dan mulut saat melaksanakan salat ataupun menutup hidung dan mulut di luar salat. ${ }^{5}$ Senada dengan itu Al Zailāì' menyebutkan bahwa al talaśšum adalah menutup hidung dan mulut saat salat. ${ }^{6}$ Lalu beliau menerangkan bahwa hal ini dimakruhkan karena menyerupai kaum Majusi ketika sedang beribadah menyembah api.

\section{b. Definisi Niqob}

Imam asy Syaukānī menjelaskan bahwa niqab adalah sebuah penutup wajah yang memiliki celah pada bagian mata yang digunakan oleh wanita untuk melihat. ${ }^{7}$

Senada dengan di atas Syekh Al Ușaimīn mengatakan Niqāb adalah penutup wajah yang digunakan oleh seorang wanita muslimah, dimana penutup wajah tersebut memiliki celah di bagian mata yang digunakan oleh penggunanya untuk melihat. ${ }^{8}$

\section{Hukum Menggunakan Penutup Wajah Saat Salat}

Menutup wajah ketika sedang melaksanakan salat pada dasarnya terlarang dalam syariat sebagaimana ditegaskan dalam sebuah hadis yang diriwayatkan dari Abū Hurairah radhiallahu 'anhu, beliau berkata;

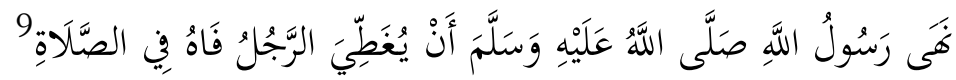

Artinya: "Rasulullah shallallahu 'alaihi wa sallam melarang seseorang menutup mulutnya ketika shalat."

Imam Abū Dāud dalam kitabnya Sunan Abī Dāud menjelaskan hadis ini menunjukkan bahwa hukum asal dalam salat adalah tidak menggunakan penutup

${ }^{4}$ Wizārah Al Auqāf Fi Syuun Al Islāmiyah, Al Mausūah Al Fiqhiyyah, edisi 1. Volume 32. (Kuwait: Wizārah Al Auqāf Fi Syuun Al Islāmiyah, 1983), 210.

${ }^{5}$ Abdullah Ibn Aḥmad Ibn Qudāmah Al Magdisī, Al Mughnī Fì Figh Al Imām Aḥmad Ibn Ḥanbal Al Syaibānī, Volume 1. (Bairūt: Dār Al Fikr 1405H), 341.

${ }^{6}$ Fakhruddīn Us̉mān Ibn A'lī Al Zailaī Al Hạāāī, ' Tabȳ̄n Al Haqāiq Syarh Kanz Al Daqāiq, Volume 1. (Al Qāhirah: Al Maṭba'ah Al Kubrā Al Amiriyyah, 1313H). 164.

${ }^{7}$ Muḥammad Ibn A'lī Ibn Muḥammad Al Syaukānī, Nail Al Autār Min Aḥādīs Sayyid Al Akhyār Syarh Muntaqā Al Akhyār, Volume 5. (Miṣr: Dār Al Hadīì, 1413H), 53.

${ }^{8}$ Muḥammad Ibn Șāleh Ibn Muḥammad Al Uśaimīn, Al-Syarh Al Mumti' A'lā Zād Al Mustaqni', edisi. I. Volume 7 (Saudi: Dār Ibn Al Jauzī, 1422H), 134.

${ }^{9}$ Muhammad Ibn Yazīd Abū Abdillah Al Quzwainī, Sunan Ibn Mājah, Volume I. (Bairūt: Dār Ihyā Al Kutub Al Arābiyyah, t.t), 310. 
wajah, meskipun kata beliau tidak mengapa bagi seseorang menggunakan penutup wajah jika ada tuntutan hajat yang mengharuskan untuk menggunakannya.

Al Imam Ibnu Așīr mengatakan yang dimaksud dari pelarangan menutup mulut dalam hadis ini adalah at Talaśśum yaitu menutup mulut dengan menggunakan Imamah. ${ }^{10}$ Menurut Imam Asy Syairāzī bahwa hukum menutup wajah saat salat adalah makruh. ${ }^{11}$ Hal yang sama dipaparkan oleh Syekh Al Islām Zakariyah Al Aṣhārī dalam kitabnya Asna Al Mathālib fi Syarh Raudh Al Mațālib bahwa dimakruhkan seorang lakilaki menutup mulutnya (At-Talatssum) sebagaimana seorang wanita juga dilarang salat dengan menggunakan Niqāb. ${ }^{12}$

Imām al-Khațābī mengatakan bahwa at Talaśšum merupakan kebiasaan bangsa Arab, di mana mereka mengenakan imamah untuk menutupi mulut. Oleh sebab itu merekapun dilarang dari perbuatan tersebut ketika dalam salat. Kecuali jika ia menguap saat salat, maka dianjurkan baginya untuk menutup mulutnya, karena adanya kebutuhan untuk itu. ${ }^{13}$

Al-Syaikh Ibnu Uṡaimīn rahimahullah mengatakan,

$$
\begin{aligned}
& \text { يكره اللثام على فمه وأنفه بأن يضع 》الغترة《 أو 》العمامة《)، أو 》الشماغن《 على فمه، وكذلك على أنفه؛ } \\
& \text { لأن النبي صلى الله عليه وسلم فى أن يغطي الرجل فاه في الصلاة، ولأنه قد يؤدي إلى الغم وإلى عدم بيان } \\
& \text { الحروف عند القراءة والذكر. ويستثنى منه ما إذا تثاءب وغطى فمه ليكظم التثاؤب فهذا لا بأس به، أما } \\
& \text { بلدون سبب فإنه يكره، فإن كان حوله رائحة كريهة تؤذيه في الصلاة، واحتاج إلى اللثام فهذا جائز؛ لأنه } \\
& \text { للحاجة، وكذلك لو كان به زكام، وصار معه حساسية إذا لم يتلثم، فهذه أيضاً حاجة تبيح أن يتلثم } 14
\end{aligned}
$$

“Dimakruhkan al-litsām pada mulut dan hidung, yaitu menutup mulut dan hidung menggunakan Ghuțrah, imāmah, atau syimāgh (sorban). Nabi shallallahu 'alaihi wa sallam telah melarang seseorang menutup mulutnya ketika melaksanakan salat. Hal itu juga terkadang mengganggu dan mengaburkan lafadz ketika membaca ayat alQuran dan dzikir salat. Namun, terdapat pengecualian jika seorang bersin dalam salat. Dalam hal ini tidak mengapa jika ia menutup mulutnya dengan tangan untuk meredakan bersin. Adapun jika hal itu dilakukan tanpa alasan, maka dimakruhkan. Apabila ada bau tidak sedap di sekitarnya sehingga bisa mengganggu salat yang akan dilaksanakan, maka boleh menggunakan al-litsām (masker) karena ada hajat yang menuntutnya. Demikian pula jika seseorang sedang menderita flu dan ia dalam

${ }^{10}$ Majduiddīn Abū Al Saādāt Al Mubārak Ibn Muḥammad Ibn Muhammad Ibn Muḥammad Ibn Abdil K3rīm Al Syaibānī Al Jazarī Ibn Al As̀īr, Al Nihaya Ficgarīb Al Hadīì Wa Al Aśar,Volume 2. (Bairūt: Al Maktabah Al Ilmiyyah, 1399H), 355.

${ }^{11} \mathrm{Ibrāhīm} \mathrm{Ibn} \mathrm{A'lī} \mathrm{Ibn} \mathrm{Yūsuf} \mathrm{Al} \mathrm{Syairāzī,} \mathrm{Al} \mathrm{Muhażżab} \mathrm{Fi} \mathrm{Fiqh} \mathrm{Al} \mathrm{Imām} \mathrm{Al} \mathrm{Syāfi't̄,} \mathrm{Volume} \mathrm{1.} \mathrm{(Bairūt:}$ Dār Al Kutub Al Ilmīyah, 1412H), 66.

${ }^{12}$ Syekh Al Islām Zakariyā Al Anșārī, Asna Al Mațālib Fi Syarh Rauḍa Al Mațālib, Volume 1. (Bairūt: Dār Al Kutub Al Ilmiyyah 1422H), 179.

${ }^{13} \mathrm{Abu}$ Sulaimān Ḥamd Ibn Muḥammad Ibn Ibrāhīm Ibn Al Khațāb Al Bustī Al Khațțābī Ma'ālim Al Sunan Syarh Sunan Abì Dāud, edisi I. Volume I. (Halab: Al Maṭbaah AL Ilmiyyah, 1932), 433.

${ }^{14}$ Muḥammad Ibn Ṣāleh Ibn Muḥammad Al Usaimīn, Al-Syarh Al Mumti' A'lā Zāed Al Mustaqni', edisi 1, Volume 3. (Saudi Arabiyah :.Dār Ibn Al Jauzī, 1422H), 179. 
keadaan sensitif apabila ia tidak menutup mulut dan hidung justru akan memperparah, maka ini juga merupakan kondisi hajat yang menuntut diperbolehkannya menutup mulut dan hidung ketika salat."

Dari Abū Sa'īd Al Khudrī radhiallahu'anhu, Nabi shallallahu 'alaihi wa sallam bersabda,

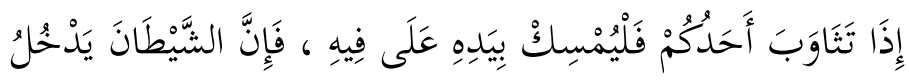

Artinya: "Jika kalian menguap, maka tutuplah mulut dengan tangan karena setan akan masuk."

Dalam redaksi lain tercantum,

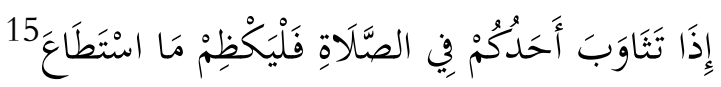

Artinya: "Jika kalian menguap dalam salat, maka tahanlah sebisa mungkin."

\section{Bagaimana Hukum Menggunakan Penutup Wajah Saat Salat Pada Kondisi Darurat}

Sebagaimana yang telah dipaparkan di atas, hukum menggunakan penutup wajah atau masker saat salat adalah makruh (makruh Tanzih) yang tidak sampai membatalkan ibadah salat.

Al-Nawāwī rahimahullah mengatakan,

$$
\text { وتثاءب فإن المهن أن يصلي الرجل متلثما أي مغطيا فاه بيده أو غيرها ويكره أن يضع يده على فمه في الصلاة إلا إذا }
$$

“Menutup mulut dan hidung (at Talaśśum) atau menutup mulut saja dengan tangan atau yang lain ketika shalat, dimakruhkan. Dimakruhkan juga, menutup mulut dengan tangan. Kecuali apabila seseorang bersin dalam shalat, maka diperbolehkan menutup mulut karena dalam kondisi ini yang sesuai sunnah adalah menggunakan tangan untuk menutup mulut sebagaimana pengajaran yang terdapat dalam hadis Șahịh Muslim (hadis Abū Sa'îd al-Khudrī di atas) ... Wanita dan banci memiliki ketentuan yang sama dengan laki-laki dalam hal ini. Perbuatan ini hukumnya makruh tanzih, sehingga tidak menghalangi keabsahan salat."

Al Imām ibn Abdil Bār mengatakan bahwa hukum makruh ini tidak mengapa dilanggar jika ada hajat/kebutuhan mendesak untuk melakukannya:

${ }^{15}$ Muslim Ibn Al Ḥajjāj Abū Al Ḥasan Al Qusyairī Al Nasisābūrī, Șaḥịh Muslim, Volume 4. (Bairūt: Dār Ihyā Al Turās Al Arabī, 2006), 2293.

${ }^{16} \mathrm{Abū}$ Zakariyā Mahyuddīn Yahyā Ibn Syaraf Al Nawāwī, Al-Majmū' Syarh Al Muhażżab, Volume 3. (Balad Al Amīn: 1999), 179. 


$$
\begin{aligned}
& \text { أجععوا على أن على المرأة أن تكشف وجهها في الصلاة والإحرام، ولأن ستر الوجه يخل بمباشرة } \\
& \text { المصلي بالجبهة والأنف ويغطي الفم، وقد فهى النبي صلى الله عليه وسلم الرجل عنه، فإن كان لحاجة } \\
& \text { كحضور أجانب فلاكراهة، وكذلك الرجل تزول الكراهة في حقه إذا احتاج إلى ذلك } 17 \text {. }
\end{aligned}
$$

“Ulama telah bersepakat bahwa seorang wanita dan pria jika melaksanakan salat dan berihram hendaknya membuaka penutup wajahnya. Karena menggunakan penutup wajah saat salat dapat menghalangi dahi dan hidung menyentuh tempat sujud. Akan tetapi, Jika seorang wanita khawatir terlihat oleh laki-laki yang bukan mahramnya, maka tidak mengapa ia menggunakan penutup wajah. Hukum ini berlaku juga untuk kaum pria jika ada hajat untuk itu.

Majma' Al Buḥ̄is Al Islāmiyah Al Azhar Al Syarîf setelah menjelaskan hadis Rasulullah yang diriwatyatkan dari Abī Hurairah Radhiallahu A'nhu tentang pelarangan menutup wajah saat salat dengan mengatakan bahwa hukum pelarangan di sini adalah Makruh Tanzih yang tidak membatalkan salat. Majma' Al Buhūis Al Islāmiyah Al Azhar Al Syarîf selanjutnya memutuskan

$$
\text { والكراهة تندفع بالحاجة، فمتى وجدت الحاجة الداعية لستر الفم أو الأنف فلا كراهة18 }
$$

"Hukum makruh bisa gugur dikarenakan adanya hajat. Oleh karena itu, jika ada hajat untuk menutup hidung dan mulut saat salat maka hukumnya boleh

Pada kondisi merebaknya virus Covid-19 akhir-akhir ini, dapat dipahami bahwa menggunakan masker atau penutup mulut dan hidung ketika melaksanakan salat hukumnya boleh karena adanya hajat.

Bahkan jika ditimbang dengan menggunakan beberapa kaidah fikih Islam menyikapi kondisi darurat seperti kaidah yang berbunyi:

$$
19 \text { الضرورات تبيح المخظورات }
$$

"Keadaan darurat membolehkan suatu yang terlarang."

Atau Kaedah lainnya yang mengatakan

$$
\text { الضرر يزال } 20
$$

"Segala bentuk kemudaratan, mesti dihilangkan sebisa mungkin"

Maka hukum menggunakan alat kesehatan pelindung diri seperti masker, bisa meningkat dari boleh menjadi dianjurkan khususnya bagi yang sedang dalam kondisi

${ }^{17}$ Manșūr Ibn Yūnus ibn Idrīs Al Buhātī, Kassyā Al Qannāa' A'n Matn Al Iqnā', Volume I. (Bairūt: Dār Al Fikr, 1402H), 268.

18 Https://Www.Elbalad.News/422184 (Diakses 25 Maret 2020)

19 Muḥammad A'mīm Al Iḥsān Al Mujaddidīal Burkatī, Qawāid Al Fihq, (Karachi: Al Ṣadf Bibalsyirza, 1986), 89.

${ }^{20} \mathrm{Al}$ Syekh Zainul Ābidīn Ibn Ibrāhīm ibn Nijaim, Al Asybah Wa Al Naẓāir, (Lubnān: Dār Al Kutub Al Ilmiyah, 1980), 87. 
kurang sehat seperti batuk, flu, atau demam dimana mereka ingin melaksanakan salat secara berjamaah.

\section{Kesimpulan}

Dari penjelasan seluruh dalil Alquran dan hadis serta kaidah fikih ditambah dengan pendapat para ulama, maka bias disimpulkan bahwa:

1. Hukum asal menggunakan penutup wajah termaksud penutup mulut dan hidung (masker) adalah makruh tanziah yang tidak membatalkan ibadah salat.

2. Pada kondisi tertentu seperti adanya hajat untuk menutup wajah atau mulut dan hidung menggunakan masker atau alat kesehatan yang lain hukumnya boleh. Bahkan hukum ini bisa meningkat ke hukum dianjurkan bagi mereka yang ingin menghadiri salat jamaah sedangkan kesehatannya terganggu.

\section{Referensi}

Al Anșārī, Syekh Al Islām Zakariyā. Asna Al Mațālib Fi Syarh Rauḍa Al Mațālib Volume 1. Bairūt: Dār Al Kutub Al Ilmiyyah 1422H.

Al Buhātī, Manșūr Ibn Yūnus ibn Idrīs. Kassyā Al Qannāa' A'n Matn Al Iqnā' Volume I. Bairūt: Dār Al Fikr, 1402H.

Al Ḥanāfī, Fakhruddīn Uṡmān ibn A'lī Al Zailaī.' Tabyīn Al Haqāiq Syarh Kanz Al Daqāiq Volume 1. Al Qāhirah: Al Maṭba' ah Al Kubrā Al Amiriyyah, 1313H.

Al Islāmiyah, Wizārah Al Auqāe Fi Syuun. Al Mausūah Al Fiqhiyyah edisi 1. Volume 32. Kuwait: Wizārah Al Auqāf Fi Syuun al Islāmiyah, 1983.

Al Khaț̣ābī, Abū Sulaimān Ḥamd Ibn Muhammad ibn Ibrāhīm ibn Al Khațāb Al Bustī. Ma'ālim Al Sunan Syarh Sunan Abī Dāud edisi I. Volume 1. Halab: Al Maṭbaah AL Ilmiyyah, 1932.

Al Magdisī, Abdullah Ibn Aḥmad ibn Qudāmah. Al Mughnī Fì Fiqh al Imām Aḥmad Ibn Hanbal Al Syaibānī. Volume 1. Bairūt: Dār Al Fikr 1405H.

Al Miṣrī, Muḥammad Ibn Mukaram Manẓūr Al Afrīqī Lisan. Al Arab, Volume 12. Bairūt; Dār Șādir, t.t

Al Mujaddidīal Burkatī, Muḥammad A'mīm al Iḥsān. Qawāì Al Fihq. Karachi: Al Ṣadf Bibalsyirza, 1986.

Al Nasisābūrī, Muslim Ibn Al Ḥajjāj Abū Al Ḥasan Al Qusyairī. Șaḥīḥ Muslim Volume 4. Bairūt: Dār Ihyā Al Turās̉ Al Arabī, 2006.

Al Nawāwī, Abū Zakariyā Mahyuddīn Yahyā ibn Syaraf. Al-Majmū' Syarh Al Muhażżab Volume 3. Balad Al Amīn: 1999.

Al Quzwain̄̄, Muhammad Ibn Yazīd Abū Abdillah. Sunan Ibn Mājah Volume I. Bairūt: Dār Thyā al Kutub Al Arābiyyah, t.t. 
Al Syairāzī, Ibrāhīm Ibn A'lī ibn Yūsuf. Al Muhażżab Fi Fiqh al Imām Al Syāfi'ì Volume 1. Bairūt: Dār Al Kutub Al Ilmīyah, 1412H.

Al Syaukānī, Muḥammad Ibn A'lī ibn Muḥammad. Nail Al Autār Min Aḥādīs Sayyid Al Akhyār Syarh Muntaqā al Akhyār Volume 5. Miṣr: Dār Al Hadīs̀, 1413H.

Al Uśaimīn, Muḥammad Ibn Șāleh Ibn Muḥammad. Al-Syarh Al Mumti' A'lā Zād Al Mustaqni' edisi. I. Volume 7. Saudi: Dār Ibn Al Jauzīi, 1422H.

Https://Www.Elbalad.News/422184 (Diakses 25 Maret 2020)

Ibn Al As̀̄ìr, Majduiddīn Abū Al Saādāt Al Mubārak ibn Muhammad Ibn Muhammad Ibn Muḥammad Ibn Abdil Karīm Al Syaibānī Al Jazarī. Al Nihaya Ficgarīb Al Hadì̄̇ Wa Al Aśar Volume 2. Bairūt: Al Maktabah Al Ilmiyyah, 1399H.

Ibn Nijaim, Al Syekh Zainul Ābidīn Ibn Ibrāhīm. Al Asybah Wa Al Naẓāir. Lubnān: Dār Al Kutub Al Ilmiyah, 1980. 


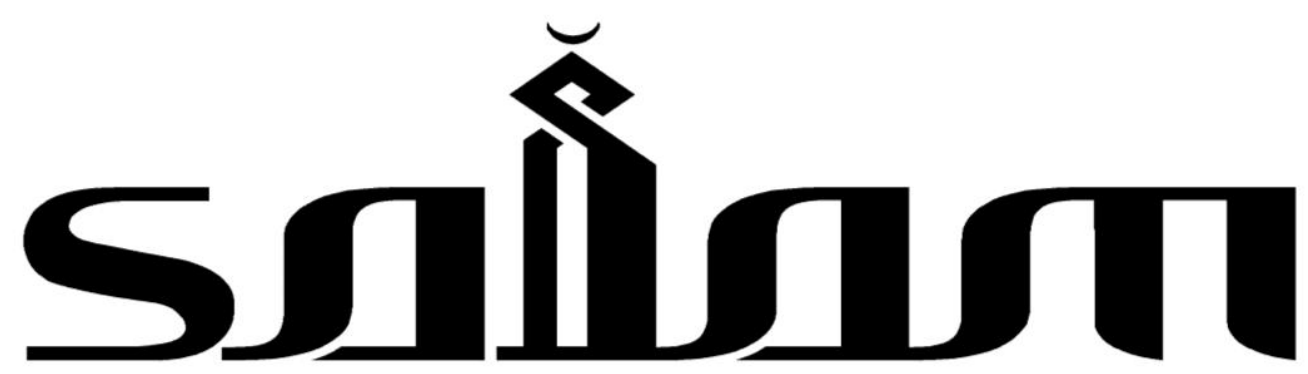

Jumnal Sosial dan Budaya Syar'i

\section{PEDOMAN TEKNIS PENULISAN BERKALA ILMIAH}

1. Artikel adalah benar-benar karya asli penulis, tidak mengandung unsur plagiasi, dan belum pernah dipublikasikan dan/atau sedang dalam proses publikasi pada media lain yang dinyatakan dengan surat pernyataan yang ditandatangani di atas meterai Rp 6000;

2. Naskah dapat berupa konseptual, resume hasil penelitian, atau pemikiran tokoh;

3. Naskah dapat berbahasa Indonesia, Inggris, Arab, maupun bahasa Rusia;

4. Naskah harus memuat informasi keilmuan dalam ranah ilmu hukum Positif;

5. Aturan penulisan adalah sebagai berikut:

a. Judul. Ditulis dengan huruf kapital, maksimum 12 kata diposisikan di tengah (centered);

b. Nama penulis. Ditulis utuh, tanpa gelar, disertai afiliasi kelembagaan dengan alamat lengkap, dan alamat e-mail;

c. Abstrak. Ditulis dalam bahasa Inggris dan Bahasa Indonesia antara 80-120 kata;

d. Sistematika penulisan naskah adalah sebagai berikut:

1) Judul;

2) Nama penulis (tanpa gelar akademik), nama dan alamat afiliasi penulis, dan e-mail;

3) Abstrak ditulis dalam dua bahasa, yaitu bahasa Indonesia dan Inggris, antara 80-120 kata;

4) Kata-kata kunci, antara 2-5 konsep yang mencerminkan substansi artikel;

5) Pendahuluan;

6) Sub judul (sesuai dengan keperluan pembahasan);

7) Penutup; dan

8) Pustaka Acuan (hanya memuat sumber-sumber yang dirujuk dan sedapat mungkin terbitan 10 tahun terakhir).

e. Ukuran kertas yang digunakan adalah kertas HVS 70 gram, ukuran A4, margin: atas $3,5 \mathrm{~cm}$, bawah $3.5 \mathrm{~cm}$, kiri $3,5 \mathrm{~cm}$, dan kanan $3,5 \mathrm{~cm}$;

f. Panjang Naskah antara 13 s.d. 15 halaman, spasi 1, huruf Palatino, ukuran 11;

g. Pengutipan kalimat. Kutipan kalimat ditulis secara langsung apabila lebih dari empat baris dipisahkan dari teks dengan jarak satu spasi dengan ukuran huruf 10 point. Sedangkan kutipan kurang dari empat baris diintegrasikan dalam teks, dengan tanda apostrof ganda di awal dan di akhir kutipan. Setiap kutipan diberi nomor. Sistem pengutipan adalah footnote (bukan bodynote atau endnote). Penulisan footnote menggunakan sistem turabian. Setiap artikel, buku, dan sumber lainnya yang dikutip harus tercantum dalam pustaka acuan;

h. Pengutipan Ayat Alquran dan Hadis. Ayat yang dikutip menyertakan keterangan ayat dalam kurung, dengan menyebut nama surah, nomor surah, dan nomor ayat, seperti (Q.s. al-Mu'min [40]: 43). Pengutipan Hadis menyebutkan nama perawi (H.r. al-Bukhārĩ dan Muslim) ditambah referensi versi cetak kitab Hadis yang dikutip. Hadis harus dikutip dari kitab-kitab Hadis standar (Kutub al-Tis'ah);

i. Cara pembuatan footnote. Footnote ditulis dengan font Palation size 9, untuk pelbagai sumber, antara lain: 
1) Buku: nama utuh penulis (tanpa gelar), judul buku (tempat terbit: penerbit, tahun terbit), cetakan, volume, juz, halaman. Contoh: Soerjono Soekanto, Pokok-pokok Sosiologi Hukum, (Jakarta: Rajawali Pers, 1986), h. 10.

2) Buku terjemahan, contoh: Roscoe Pound, Pengantar Filsafat Hukum: Buku III, diterjemahkan oleh Moh. Radjab, (Jakarta: Bharata, 1963), h. 15;

1) Jurnal, contoh: Nur Rohim, "Kontroversi Pembentukan Perppu No. 1 Tahun 2013 tentang mahkamah konstitusi dalam ranah kegentingan yang memaksa", dalam Jurnal Cita Hukum, Vol. 2, No. 1 (2014), h. 157.

2) Artikel sebagai bagian dari buku (antologi), contoh: Hikmahanto Juwana, "Penegakan Hukum dalam Kajian Law and Development: Problem dan Fundamen bagi Solusi Indonesia", dalam Muhammad Tahir Azhary, Beberapa Aspek Hukum Tata Negara, Hukum Pidana, dan Hukum Islam, (Jakarta: Kencana Prenada Media Gorup, 2012), h. 127.

3) Artikel dari internet, contoh: Ahmad Tholabi Kharlie, "Problem Yuridis RUU Syariah" dalam http://ahmadtholabi.com/2008/03/03/problem-yuridis-ruu-syariah, diunduh pada 20 Maret 2012.

4) Artikel dari majalah, contoh: Susilaningtias, "Potret Hukum Adat pada Masa Kolonial", dalam Forum Keadilan, No. 17, 20 Agustus 2006.

5) Makalah dalam seminar, contoh: Jimly Asshiddiqie, "Kedudukan Mahkamah Konstitusi dalam Struktur Ketatanegaraan Indonesia", Makalah disampaikan dalam Kuliah Umum Fakultas Hukum Universitas Sebelas Maret, Surakarta, pada 2 Maret 2004.

j. Pustaka Acuan: daftar pustaka acuan ditulis sesuai urutan abjad, nama akhir penulis diletakkan di depan. Contoh:

1) Buku, contoh: Soekanto, Soerjono, Pokok-pokok Sosiologi Hukum, Jakarta: Rajawali Pers, 1986.

2) Buku terjemahan, contoh: Pound, Roscoe, Pengantar Filsafat Hukum: Buku III, diterjemahakan oleh Moh. Radjab, Jakarta: Bharata, 1963.

3) Jurnal, contoh: Rohim, Nur, "Kontroversi Pembentukan Perppu No. 1 Tahun 2013 tentang mahkamah konstitusi dalam ranah kegentingan yang memaksa", dalam Jurnal Cita Hukum, Vol. 2, No. 1 (2014).

4) Artikel sebagai bagian dari buku, contoh: Juwana, Hikmahanto, "Penegakan Hukum dalam Kajian Law and Development: Problem dan Fundamen bagi Solusi Indonesia", dalam Muhammad Tahir Azhary, Beberapa Aspek Hukum Tata Negara, Hukum Pidana, dan Hukum Islam, Jakarta: Kencana Prenada Media Gorup, 2012.

5) Artikel yang dikutip dari internet, contoh: Kharlie, Ahmad Tholabi, "Problem Yuridis RUU Syariah" dalam http://ahmadtholabi.com/2008/03/03/problem-yuridis-ruu-syariah, diunduh pada 20 Maret 2012.

6) Majalah, contoh: Susilaningtias, "Potret Hukum Adat pada Masa Kolonial", dalam Forum Keadilan, No. 17, 20 Agustus 2006.

7) Makalah dalam seminar, contoh: Asshiddiqie, Jimly, "Kedudukan Mahkamah Konstitusi dalam Struktur Ketatanegaraan Indonesia", Makalah disampaikan dalam Kuliah Umum Fakultas Hukum Universitas Sebelas Maret, Surakarta, pada 2 Maret 2004.

k. Penutup: artikel ditutup dengan kesimpulan;

I. Biografi singkat: biografi penulis mengandung unsur nama (lengkap dengan gelar akademik), tempat tugas, riwayat pendidikan formal (S1, S2, S3), dan bidang keahlian akademik;

6. Setiap naskah yang tidak mengindahkan pedoman penulisan ini akan dikembalikan kepada penulisnya untuk diperbaiki.

7. Naskah sudah diserahkan kepada penyunting, selambat-lambatnya tiga bulan sebelum waktu penerbitan (April, Agustus. dan Desember) dengan mengupload pada laman OJS jurnal pada alamat http://journal.uinjkt.ac.id/index.php/salam atau dikirim langsung via e-mail ke: jurnal.salam@gmail.com atau nurrohimyunus@uinjkt.ac.id..] 


\section{Indexed by :}
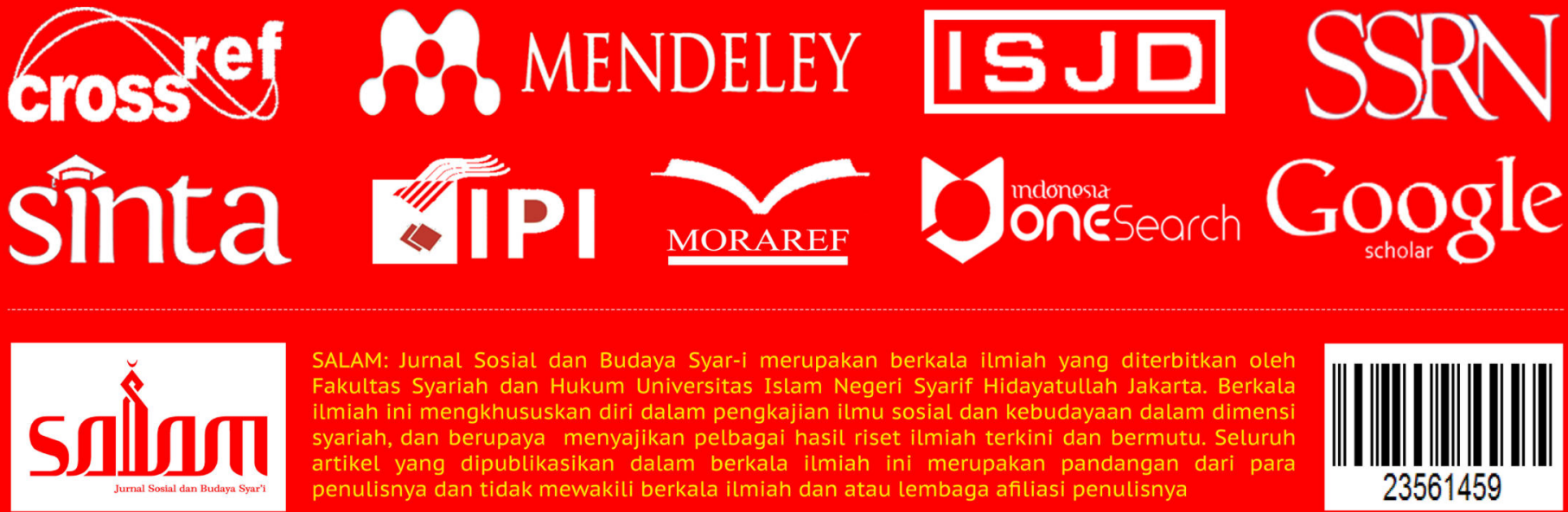

SALAM: Jurnal Sosial dan Budaya Syar-i merupakan berkala ilmiah yang diterbitkan oleh Fakultas Syariah dan Hukum Universitas Islam Negeri Syarif Hidayatullah Jakarta. Berkala ilmiah ini mengkhususkan diri dalam pengkajian ilmu sosial dan kebudayaan dalam dimensi syariah, dan berupaya menyajikan pelbagai hasil riset ilmiah terkini dan bermutu. Seluruh artikel yang dipublikasikan dalam berkala ilmiah ini merupakan pandangan dari para penulisnya dan tidak mewakili berkala ilmiah dan atau lembaga afiliasi penulisnya

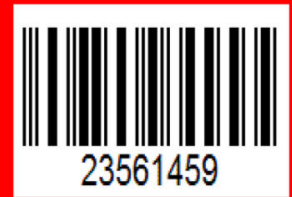

